\title{
PHOSPHORUS AVAILABILITY CHANGES THE INTERNAL AND EXTERNAL ENDOMYCORRHIZAL COLONIZATION AND AFFECTS SYMBIOTIC EFFECTIVENESS
}

\author{
Marco Antonio Nogueira ${ }^{1 *}$; Elke Jurandy Bran Nogueira Cardoso ${ }^{2}$ \\ ${ }^{1}$ UEL - Depto. de Microbiologia, Lab. de Ecologia Microbiana, C.P. 6001 - 86051-990 - Londrina, PR - Brasil. \\ ${ }^{2}$ USP/ESALQ - Depto. de Ciência do Solo, C.P. 9 - 13418-900 - Piracicaba, SP - Brasil. \\ *Corresponding author <nogueira@uel.br>
}

\begin{abstract}
Despite the awareness that high phosphorus (P) availability decreases the mycorrhizal root colonization in higher plants, the effects on the external mycelium are contradicting. The aim of this work was to assess the external mycelium of the arbuscular mycorrhizal fungi (AMF) Glomus intraradices and Gigaspora rosea, associated to soybean under increasing P levels $(0,25,50,100$ and $200 \mathrm{mg} \mathrm{kg}^{-1}$ ). The tested hypotheses were: a) the amount of external mycelium depends on the fungal species; b) the P levels affect diferentially each mycorrhizal species; c) the mycorrhizal effectiveness depends on the amount of external mycelium. Mycorrhizal stimulus on plant biomass occurred at $\mathrm{P}$ levels of 0,25 and $200 \mathrm{mg} \mathrm{kg}^{-1}$. Mycorrhizal root colonization and total external mycelium (TEM) decreased with increasing P levels. At zero P level, G. rosea produced less TEM than G. intraradices, which may be related to the lower mycorrhizal effectiveness for $G$. rosea. Both AMF increased the active external mycelium along $\mathrm{P}$ levels, but this increase was not related with symbiotic effectiveness. TEM was found to be closely related to root colonization and mycorrhizal effectiveness. The root colonization and TEM are mutually afected by $\mathrm{P}$ availability. Althoug $G$. intraradices produced more TEM than G. rosea along the P levels, they seemed to affect similarly the TEM for both AMF. More AMF species should be assessed in order to attest whether P levels affect the external mycelium differentially among them.
\end{abstract}

Key words: arbuscular mycorrhizal fungi, external mycelium, soybean

\section{DISPONIBILIDADE DE FÓSFORO ALTERAA COLONIZAÇÃO ENDOMICORRÍZICAINTERNA E EXTERNA EAFETAA EFICIÊNCIA SIMBIÓTICA}

\begin{abstract}
RESUMO: Apesar do conhecimento de que a disponibilidade de fósforo diminui a colonização micorrízica, os efeitos sobre o micélio externo são contraditórios. O objetivo desse trabalho foi avaliar o micélio externo dos fungos micorrízicos arbusculares (FMA) Glomus intraradices e Gigaspora rosea, associados à soja, sob doses crescentes de $\mathrm{P}\left(0,25,50,100 \mathrm{e} 200 \mathrm{mg} \mathrm{kg}^{-1}\right)$. As hipóteses foram: a) a quantidade de micélio externo depende da espécie fúngica; b) cada espécie fúngica é afetada diferentemente pelas doses de P; c) a eficiência micorrízica depende da quantidade de micélio externo. Os FMA estimularam a produção de biomassa pela planta nas doses 0,25 e $200 \mathrm{mg} \mathrm{kg}^{-1}$ de P. A colonização micorrízica e o micélio externo total (MET) diminuíram com o aumento das doses de $\mathrm{P}$. Na dose zero de P, G. rosea produziu menos MET que G. intraradices, o que pode explicar a menor eficiência simbiótica dessa espécie. Ambos FMA apresentaram aumento do micélio externo ativo com $\mathrm{o}$ aumento das doses de $\mathrm{P}$, mas isso não teve relação com a eficiência simbiótica. $\mathrm{O}$ MET apresentou correlação com a colonização radicular e com a eficiência micorrízica. A colonização radicular e o MET são mutuamente afetados pela disponibilidade de P. Embora G. intraradices tenha produzido mais MET que G. rosea em todas as doses de P, estas afetaram similarmente o MET em ambos FMA. Mais fungos micorrízicos devem ser testados para avaliar se a disponibilidade de $\mathrm{P}$ afeta diferencialmente o micélio externo entre as espécies.

Palavras-chave: fungo micorrízico arbuscular, micélio externo, soja
\end{abstract}

\section{INTRODUCTION}

The main contribution of arbuscular mycorrhiza to plant growth is generally considered to be the improved mineral nutrition, mainly with respect to phosphorus (P). The mechanism by which the arbuscular mycorrhizal fungi (AMF) mines the soil for $\mathrm{P}$ is based on a greater exploration of the soil by the 
external mycelium, that can extend beyond the rhizosphere and amount up to more than $100 \mathrm{~m} \mathrm{~g}^{-1}$ of soil (Miller et al., 1995; Nogueira \& Cardoso, 2000).

Although AMF are ubiquitous in nature and colonize several hosts, not all species are effective in improving plant growth (Dodd et al., 2000). For example, Gigaspora sp. was observed to be not so effective in soybean (Nogueira \& Cardoso, 2000) and Stylosanthes guianensis (Lambais \& Cardoso, 1990), but was very effective in perennial plants (Antunes et al., 1988). An AMF species with a larger production of external mycelium is expected to be more effective in transferring nutrients to the plant. However, more external mycelium production represents more carbon drain from the host.

The most important factor influencing mycorrhizal symbiosis seems to be soil $P$ availability. Andrade et al. (2005) observed that increasing P levels reduced the mycorrhizal external hyphae. Nevertheless, several authors found exactly the opposite (Cardoso-Filho et al., 1999; Melloni \& Cardoso, 1999b; Neumann \& George, 2005). These contradictions may be caused by factors related to the host plant, endophyte, or environment.

The objective of this research was to assess the total and active external mycelium of Glomus intraradices and Gigaspora rosea on soybean under increasing P levels. The hypotheses assessed were: a) the amount of external mycelium depends on the mycorrhizal species; b) P levels affect each endophyte in a different way in relation to the external mycelium; and c) mycorrhizal effectiveness is related to the amount of external mycelium.

\section{MATERIAL AND METHODS}

Plants were grown on a sandy substrate in order to make the extraction of the external mycelium easier and to reduce the chemical fixation of P. Three parts of the top layer (0-0.2 m) of an acidic sandy soil (Typic Quartzipsamment) and one part of coarse washed sand were mixed in order to obtain the substrate. After homogenization, it was autoclaved $\left(121^{\circ} \mathrm{C} / 2 \mathrm{~h}\right)$ and a subsequent chemical analysis showed the following results: $\mathrm{pH}\left(\mathrm{CaCl}_{2}\right): 3.9$; organic matter: $12 \mathrm{~g} \mathrm{~kg}^{-1}$; $\mathrm{P}$ (resin method) and $\mathrm{S}: 3$ and $23 \mathrm{mg} \mathrm{kg}^{-1}$, respectively; $\mathrm{K}, \mathrm{Ca}, \mathrm{Mg}, \mathrm{Al}$ and $\mathrm{H}+\mathrm{Al}: 2.2$, 7.0, 3.0, 9.0, and $22 \mathrm{mmol}_{\mathrm{c}} \mathrm{dm}^{-3}$, respectively; $\mathrm{B}, \mathrm{Cu}$, $\mathrm{Fe}, \mathrm{Mn}, \mathrm{Zn}$ and $\mathrm{Na}: 0.3,0.4,64,21,2$ and $5 \mathrm{mg} \mathrm{kg}^{-1}$, respectively. Polyethylene pots received $3.2 \mathrm{~kg}$ $\left(=2.5 \mathrm{dm}^{3}\right)$ of the substrate mixed thoroughly with $2.25 \mathrm{~g}$ of $\mathrm{CaCO}_{3}$, in order to raise the $\mathrm{pH}$ to 5.0. After two weeks, each pot received $90 \mathrm{mg}$ of $\mathrm{K}(\mathrm{KCl})$ and $43 \mathrm{mg}$ of $\mathrm{S}\left(\mathrm{CaSO}_{4} \cdot 2 \mathrm{H}_{2} \mathrm{O}\right)$.
Phosphorus was supplied at five levels $(0,25$, 50,100 or $\left.200 \mathrm{mg} \mathrm{kg}^{-1}\right)$ [as ground $(<0.23 \mathrm{~mm})$ triple superphosphate, thoroughly mixed into the substrate] resulting in, respectively, 4, 19, 33, 77 and $138 \mathrm{mg}$ $\mathrm{kg}^{-1}$ of available P, just before sowing. Each P level was combined with either the AMF Gigaspora rosea, the AMF Glomus intraradices, or a non-inoculated control, in order to form a $5 \times 3$ factorial arrangement with four replications, in an entirely randomized experimental design. These two AMF were chosen because in earlier research they were found to be very contrasting with respect to mycorrhizal effectiveness on soybean (Nogueira \& Cardoso, 2000) and their hyphal morphology (Dodd et al., 2000). The AMF inoculum consisted of about 250 spores per pot for each endophyte, extracted from multiplication pots in pure culture on Brachiaria decumbens as host plant. All pots received $10 \mathrm{~mL}$ of a soil suspension (non autoclaved soil suspended in water, 1:4 w/v) passed through a set of screens, the last one with $44 \mu \mathrm{m}$ of mash, in order to restore a similar microbial community, except native AMF.

Soybean seeds (cv. IAC 8) were previously surface-sterilized with $70 \%$ ethanol for $1 \mathrm{~min}, 2 \%$ sodium hypochlorite for $3 \mathrm{~min}$, and rinsed several times with distilled water. Each pot received six seeds that were thinned to two plantlets after emergence. At this moment, $5 \mathrm{~mL}$ of a cell suspension $\left(10^{9} \mathrm{~mL}^{-1}\right)$ of Bradyrhizobium sp. (Semia 587 and Semia 5019) was poured jointly to the plantlets' stems. Plants were kept for 80 days in the greenhouse at a temperature range from $20^{\circ} \mathrm{C}$ (night) to $35^{\circ} \mathrm{C}$ (day), relative humidity of 60 to $90 \%$, PAR from 600 to $1200 \mu \mathrm{mol} \mathrm{m}^{-2} \mathrm{~s}^{-1}$ on cloudy and sunny days, respectively, and received distilled water whenever necessary. Each pot received 50 $\mathrm{mL}$ of Hoagland's micronutrient solution every two weeks.

At the end of the experimental period, shoots and roots were washed individually in a sequence of tap water, $0.1 \mathrm{~mol} \mathrm{~L}^{-1} \mathrm{HCl}$, and twice in distilled water. After root fresh weight determination, $2 \mathrm{~g}$ were stored in FAA solution $(50 \mathrm{~mL}$ ethanol, $12.5 \mathrm{~mL}$ formaldehyde, $2.5 \mathrm{~mL}$ glacial acetic acid in $100 \mathrm{~mL}$ distilled water) until root colonization assessments (Phillips \& Hayman, 1970; Giovannetti \& Mosse, 1980). Nodules and pods were detached from roots and shoots, respectively. All parts of the plant were assessed for dry biomass as usual. The mycorrhizal effectiveness (ME \%) was based on the difference between the shoot dry biomass (including pods) of mycorrhizal $(\mathrm{SDBm})$ and non-mycorrhizal (SDBnm) plants in relation to the SDBnm plants $[\mathrm{ME} \%=(\mathrm{SDBm}-$ SDBnm)*100/SDBnm]. Shoots and pods were ground separately and submitted to chemical analysis for $\mathrm{P}$ 
(metavanadate colorimetry) in the nitric-perchloric digest (Sarruge \& Haag, 1974).

The total external mycelium (TEM) (CardosoFilho et al., 1999) and active external mycelium (AEM) (Sylvia, 1992), both modified by Melloni \& Cardoso (1999a), were estimated in the substrate. Briefly, $10 \mathrm{~g}$ of wet soil were shaken in $1,500 \mathrm{~mL}$ of water in a blender for $30 \mathrm{~s}$. After settling for $2 \mathrm{~min}, 500 \mathrm{~mL}$ of the supernatant were passed through a sieve of $44 \mu \mathrm{m}$ mesh. The retained material was resuspended in $10 \mathrm{~mL}$ of phosphate buffer $\mathrm{pH}$ 7.4. An aliquot of this suspension was treated with fluorescein diacetate, an esterase substrate, which, after hydrolysis, fluoresces when excited under UV, indicating the active part of the mycelium. After incubation for five minutes in the dark, the aliquot was filtered under vacuum onto a squared $(3 \times 3 \mathrm{~mm})$ nitrocellulose membrane. Counting was performed at 400-x magnification under UV in a microscope adapted with a grid line ocular in 64 fields on the membrane surface. The TEM was counted in the same sample under white light. According to this method, the hyphae (active or total) that contact the grid line of the ocular are counted and the mycelial length is estimated by means of Newman's equation (Newman, 1966), considering the dilution rate, aliquot volume, number of fields observed, membrane area and number of hyphae contacting or crossing the lines in the ocular grid.

The analysis of variance was calculated with the procedure GLM of the statistical software SAS (SAS, 1991). In the interaction between AMF and $P$ levels, the AMF effect in each P level was compared by means of the Student's $t$ test, while the effects of $\mathrm{P}$ levels in each mycorrhizal treatment were tested by regression analysis $(P<5 \%)$. Simple regression analysis was established between TEM and root colonization and between TEM and mycorrhizal effectiveness for each mycorrhizal species.

\section{RESULTS AND DISCUSSION}

The interaction between $\mathrm{P}$ levels and AMF was significant $(P<0.05)$ in all assessed variables (data not shown). Positive effects of AMF on total plant dry weight were observed at P levels of 0,25 and $200 \mathrm{mg} \mathrm{kg}^{-1}$ (Figure 1). The mycorrhizal stimulus occurred mainly for shoots and pods and was less pronounced in roots and nodules. The significant differences were the same for total DW, shoot and pod DW at 0 and $25 \mathrm{mg} \mathrm{kg}^{-1}$ of P; and for total DW, pod, shoot, root and nodule DW at $200 \mathrm{mg} \mathrm{kg}^{-1} \mathrm{P}$. Although growth promotion caused by mycorrhizae is very common and well known, in this case there was no response at the intermediate P levels (50 and $100 \mathrm{mg} \mathrm{kg}^{-1}$ ). At zero P,

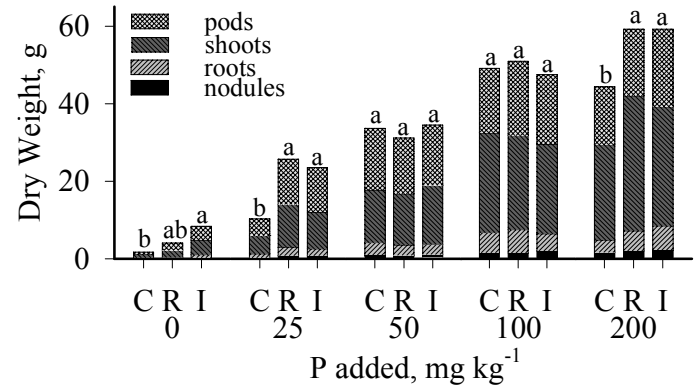

Figure 1 - Total dry weight-DW (whole bar), pod, shoot, root and nodule dry weights from non-mycorrhizal (C control) and mycorrhizal (R - Gigaspora rosea or I Glomus intraradices) soybean plants according to $\mathrm{P}$ levels in the substrate. Means in each P level sharing the same letter do not differ from each other ( $t$ test, $P<0.05)$ considering the total DW.

the extremely low P availability in the substrate (initially $4 \mathrm{mg} \mathrm{kg}^{-1}$ ) probably was responsible for not allowing $G$. rosea to show a significant increase in plant growth. Similar results were observed for sorghum plants (Bressan et al., 2001) under extremely low P availability. At $\mathrm{P}$ levels of 50 and $100 \mathrm{mg} \mathrm{kg}^{-1}$ plant growth was the same, regardless their mycorrhizal status. There is a range of $\mathrm{P}$ availability in which plant response to mycorrhiza is positive. In the case of extremely low $\mathrm{P}$ or enough available $\mathrm{P}$, plants usually do not respond to mycorrhiza. Therefore, it was not expected to find plants benefited by mycorrhizal symbiosis at the highest P level. However, other mechanisms could have contributed to the enhanced growth of mycorrhizal plants at this condition, including hormonal effects of AMF or other microorganisms in the mycorrhizosphere (Barea et al., 2002).

$\mathrm{P}$ concentrations in shoots followed a quadratic increase along the $\mathrm{P}$ levels, while $\mathrm{P}$ concentrations in pods followed a linear increase (Figures 2A and 2B), irrespective to mycorrhiza. Similar P concentrations in shoots were found when soybean plants had received up to $100 \mathrm{mg} \mathrm{kg}^{-1} \mathrm{P}$ in an oxidic soil (Bressan et al., 2001). At $200 \mathrm{mg} \mathrm{kg}^{-1} \mathrm{P}$, however, our results were three times higher. This is attributed to higher $\mathrm{P}$ fixation in the clayey, oxidic soil (only $34 \mathrm{mg} \mathrm{kg}^{-1}$ of available $\mathrm{P}$ ) as compared to the sandy soil here used (138 $\mathrm{mg} \mathrm{kg}^{-1}$ of available P).

Mycorrhizal root colonization decreased sharply with $\mathrm{P}$ addition (Figure 3A). The level fell from about $70 \%$ to less than $20 \%$ at the highest P level. In this case, G. rosea was more sensitive to $\mathrm{P}$ addition and followed a quadratic decrease in comparison to $G$. intraradices that followed a linear decrease. Nevertheless, the root colonization was similar at the highest P level. Even reduced, the mycorrhizal colonization was enough to increase total plant DW at this $\mathrm{P}$ level. Similar decrease in root colonization was ob- 

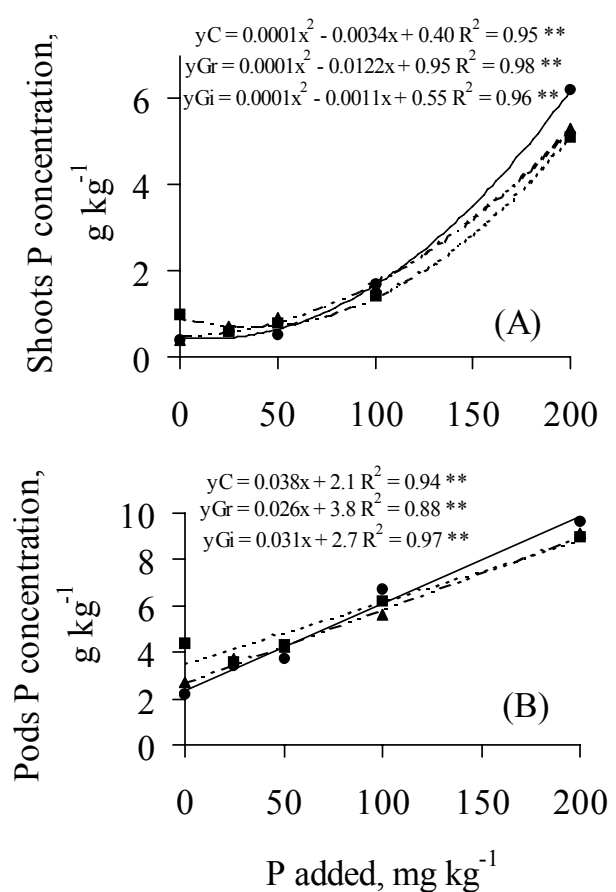

Figure 2 - $\mathrm{P}$ concentrations in the shoots $(\mathrm{A})$ and pods $(\mathrm{B})$ in non-mycorrhizal $(\longrightarrow=$ control, $\mathrm{yC})$ or mycorrhizal (------ = Gigaspora rosea, yGr; ..-A.= Glomus intraradices, yGi) soybean plants, according to $\mathrm{P}$ levels in the substrate. $*$ and $* *=$ regressions significative at $P<0.05$ and $P<0.01$, respectively.
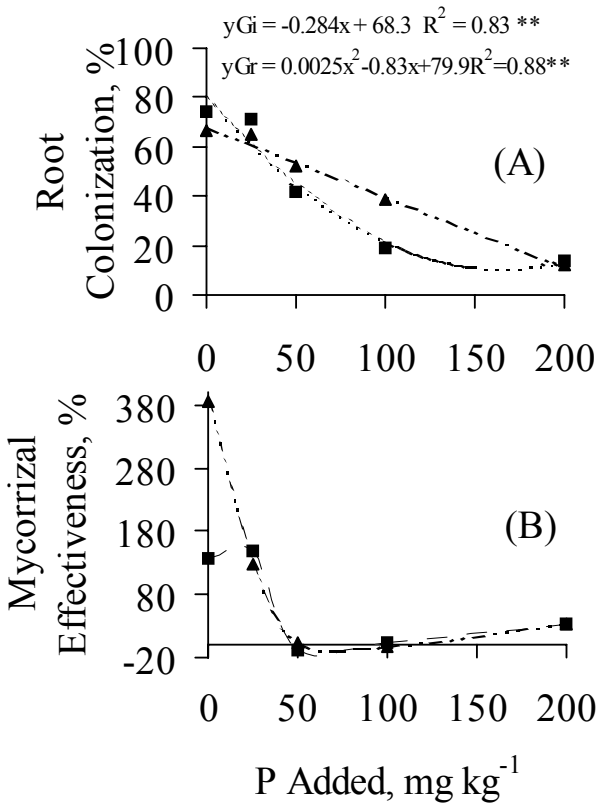

Figure 3 - Root colonization (A) and mycorrhizal effectiveness (B) of Gigaspora rosea (-----, yGr) and Glomus intraradices (.-A- , yGI) on soybean according to $\mathrm{P}$ levels in the substrate. ${ }^{* *}=$ regressions significative at $P<0.01$. served in a previous study, conducted under similar conditions (Nogueira \& Cardoso, 2000). In that case, Gigaspora margarita showed greater root colonization than $G$. intraradices at 100 and $200 \mathrm{mg} \mathrm{kg}^{-1}$ of P. In addition, G. margarita colonized the root system more slowly, a behavior that could explain in part its lower effectiveness in soybean, when compared to $G$. intraradices (Figure 3B). The mycorrhizal effectiveness was very evident at 0 and $25 \mathrm{mg} \mathrm{kg}^{-1}$ of $\mathrm{P}$, but $G$. intraradices was much more effective than $G$. rosea at $\mathrm{P}$ level zero.

Considering the treatments with AMF, the AEM increased linearly along the $\mathrm{P}$ levels and was similar for both AMF (Figure 4A). In contrast, TEM fell in a quadratic way in response to $\mathrm{P}$ increase (Figure
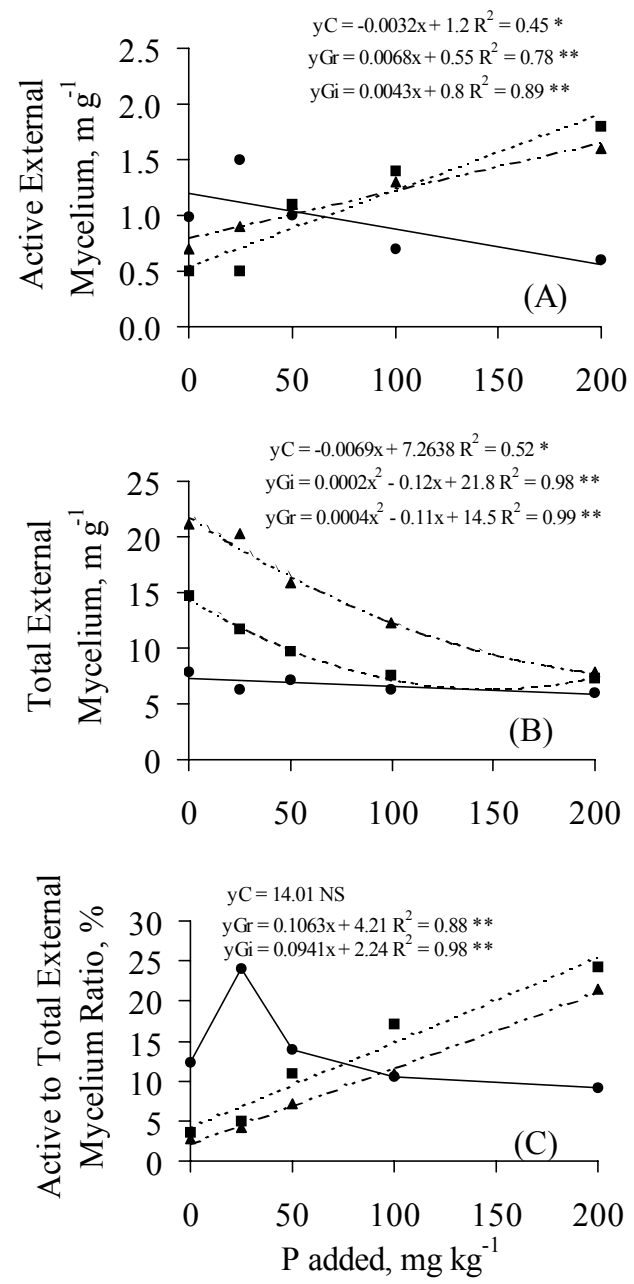

Figure 4 - Active external mycelium (A), total external mycelium (B) and active to total external mycelium ratio (C) estimated in substrate containing non-mycorrhizal $\left(\longrightarrow \_\right.$= control, $\left.\mathrm{yC}\right)$ or mycorrhizal (----- $=$ Gigaspora rosea, yGr; ..-A.- = Glomus intraradices, yGi) soybean plants, according to P levels in the substrate. $*$ and $* *=$ regressions significative at $P<0.05$ and $P<0.01$, respectively. $\mathrm{NS}=$ not significative. 
4B). These results conflict with previous findings in which the AEM decreased with P increase (Nogueira $\&$ Cardoso, 2000) or remained stable (Cardoso-Filho et al., 1999; Nogueira \& Cardoso, 2006) but corroborate another work in which the AEM increased, depending on the host plant (Melloni \& Cardoso, 1999b). The amount of AEM, less than $2.0 \mathrm{~m} \mathrm{~g}^{-1}$, was comparable to that found in citrus experiments (Melloni \& Cardoso, 1999 b), but lower than in experiments with maize (Cardoso-Filho et al., 1999), who found up to $12 \mathrm{~m} \mathrm{~g}^{-1}$, depending on the P level and plant age. Probably the host plant exerts direct effect on the AEM production. In addition, the life cycle of the soybean plant could have contributed to lessen the AEM. During the reproductive stage (grain formation, as was the case) there is strong $\mathrm{C}$ drain from roots to shoots, and the symbionts in the roots starve. As a result, less metabolically active mycorrhizal mycelium would be formed.

The amount of TEM found in this experiment was comparable to previous findings (Sylvia, 1988; Cardoso-Filho et al., 1999; Andrade et al., 2005; Nogueira \& Cardoso, 2006). Other evaluations for hyphal lengths of filamentous fungi under natural conditions, however, reached even much higher values, up to more than $100 \mathrm{~m} \mathrm{~cm}^{-3}$ of soil (Miller et al., 1995). Although the differentiation of mycorrhizal hyphae from that of other filamentous fungi in the soil is quite difficult (Sylvia, 1992), at least 35 to $70 \%$ of the total is expected to be from mycorrhizal fungi (Cardoso-Filho et al., 1999). Although at lower amount, some AEM and TEM were found in the control treatments (Figure 4A, 4B). It must be emphasized that the soil was reinoculated with a suspension of original soil in order to reestablish the native microbial community, except native AMF. In this case, the mycelium found in the substrate was originated from other non-mycorrhizal filamentous fungi. As stated above, the distinction of mycorrhizal from non-mycorrhizal hyphae is not always possible (Sylvia, 1992). However, given that no trace of mycorrhizal root colonization was found in the controls, it can surely be affirmed that the mycelium found in that treatment were not mycorrhizal.

The proportion between AEM/TEM (Figure 4C) was similar between AMF and increased linearly with $\mathrm{P}$ levels, ranging from less than $4 \%$ to more than $20 \%$ at 0 and $200 \mathrm{mg} \mathrm{kg}^{-1}$ of $\mathrm{P}$, respectively. These results are exactly the opposite of others (CardosoFilho et al., 1999) in which the ratio between AEM to TEM decreased with $P$ increase in the substrate. Many factors, such as initial $\mathrm{P}$ levels in the soil, $\mathrm{P}$ fixation in the soil, $\mathrm{P}$ sources and their solubilities, may affect the AEM/TEM proportion (Cardoso-Filho et al., 1999). Moreover, some factors such as host age and host and soil types probably also affect this proportion.
In opposition to AEM, the TEM was very sensitive to increasing P levels in the substrate (Figure 4B). At the highest $\mathrm{P}$ level, the amounts did not differ from those of the AMF-free control. Similar decrease in TEM was observed previously in response to increasing $\mathrm{P}$ (Andrade et al., 2005), but in some cases there were increases in TEM with $\mathrm{P}$ addition in the substrate (Cardoso-Filho et al., 1999; Neumann \& George, 2005) or no change (Nogueira \& Cardoso, 2006). However, soil type and host plant were different in those experiments. G. rosea produced less TEM than $G$. intraradices at P levels lower than $200 \mathrm{mg} \mathrm{kg}^{-1}$. Nevertheless, the increasing $\mathrm{P}$ availability was harmful for both. Thus, $G$. intraradices produced about $22 \mathrm{~m} \mathrm{~g}^{-1}$ of TEM at the 0 P level, while G. rosea produced only $15 \mathrm{~m} \mathrm{~g}^{-1}$ in the same condition. The amount of TEM from $G$. intraradices was similar in previous work under low $\mathrm{P}$ condition, in which other Glomus sp. species produced less TEM (Andrade et al., 2005). When P levels increased, G. rosea intrinsically continued producing less TEM than $G$. intraradices. Previous findings showed that Gigaspora was usually less effective on Stylosanthes guianensis and soybean growth than Glomus species (Lambais \& Cardoso, 1990; Nogueira \& Cardoso, 2000). It is possible that the lower effectiveness of Gigaspora on soybean growth was partially due to the lower external mycelium production in symbiosis with this plant.

Another point to consider is that TEM increases along the time after the establishment of the symbiosis (Nogueira \& Cardoso, 2006). AEM, which represents only the percentage of hyphae that are active at the moment at which the host plant is harvested, may be a much more dynamic figure, with periods of increases and decreases during the host's life cycle. Therefore, TEM is much more reliable than AEM for detecting mycorrhizal effectiveness.

Under extreme $\mathrm{P}$ deficiency, the greater amount of external mycelium produced by $G$. intraradices may have helped the plant, when compared to G. rosea. Indeed, G. intraradices produced more TEM than G. rosea along all $\mathrm{P}$ levels. In addition, the mycorrhizal effectiveness for $G$. rosea was less interrelated to the total external mycelium length than it was for $G$. intraradices (Figure 5A). In the case here reported, the internal root colonization also showed strong relationship with the TEM for both AMF (Figure 5B). This seems to suggest that any feature affecting the internal phase of the endophyte do also affect the external one. In this experiment, $\mathrm{P}$ levels seemed to affect similarly the root colonization and TEM for both AMF. In order to attest whether P levels affect the external mycelium differentially among AMF species, a wider range of species should be tested. 



Total External Mycelium, $\mathrm{m} \mathrm{g}^{-1}$
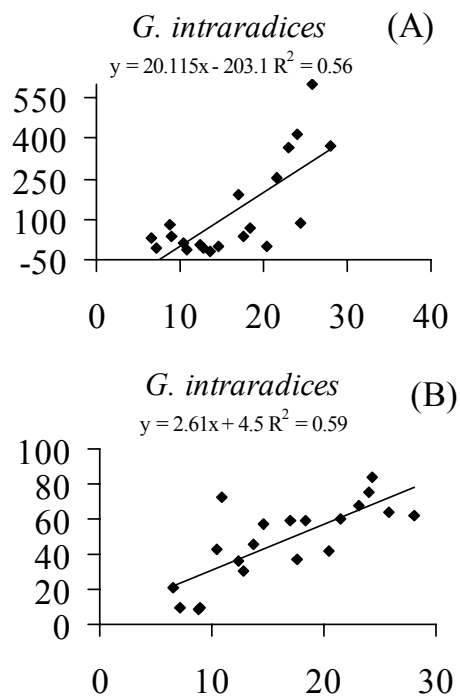

Total External Mycelium, $\mathrm{m} \mathrm{g}^{-1}$

Figure 5 - Regression between mycorrhizal effectiveness and total external mycelium (A), and between percentage of root colonization and total external mycelium (B) for each endophyte $(n=20)$.

\section{AKNOWLEDGEMENTS}

To Denise de Lourdes Colombo Mescolotti and Luís Fernando Baldesin for their assistance during the installation, conduction and analysis of the experiment, and to $\mathrm{CNPq}$ for scholarships.

\section{REFERENCES}

ANDRADE, S.A.L.; JORGE, R.A.; SILVEIRA, A.P.D. Cadmium effect on the association of jackbean (Canavalia ensiformis) and arbuscular mycorrhizal fungi. Scientia Agricola, v.62, p.389-394, 2005.

ANTUNES, V.; SILVEIRA, A.P.; CARDOSO, E.J.B.N. Interação entre diferentes tipos de solo e fungos micorrízicos vesículoarbusculares na produção de mudas de café (Coffea arabica, L.). Turrialba, v.38, p.117-122, 1988.

BAREA, J.M.; AZCÓN, R.; AZCÓN-AGUILAR, C. Mycorrhizosphere interactions to improve plant fitness and soil quality. Antonie van Leeuwenhoek, v.81, p.343-351, 2002.

BRESSAN, W.; SIQUIERA, J.O.; VASCONCELLOS, C.A.; PURCINO, A.A.C. Fungos micorrízicos e fósforo, no crescimento, nos teores de nutrientes e na produção de sorgo e soja consorciados. Pesquisa Agropecuária Brasileira, v.36, p.315-323, 2001 .

CARDOSO-FILHO J.; PACOVSKY, R.S.; CARDOSO, E.J.B.N. Growth and metabolic activity of the extramatricial mycelium of endomycorrhizal maize plants. Revista Brasileira de Ciência do Solo, v.23, p.807-815, 1999.

DODD, J.C.; BODDINGTON, C.L.; RODRIGUEZ, A.; GONZALESCHAVEZ, C.; MANSUR, I. Mycelium of arbuscular mycorrhizal fungi (AMF) from different genera: form, function and detection. Plant and Soil, v.226, p.131-151, 2000.

GIOVANNETTI, M.; MOSSE, B. An evaluation of techniques for measuring vesicular-arbuscular mycorrhizal infection in roots. New Phytologist, v.84, p.489-500, 1980.

LAMBAIS, M.R.; CARDOSO, E.J.B.N. Response of Stylosanthes guianensis to endomycorrhizal fungi inoculation as affected by lime and phosphorus applications. Plant and Soil, v.129, p.283-289, 1990.
MELLONI, R.; CARDOSO, E.J.B.N. Quantificação de micélio extrarradicular de fungos micorrízicos arbusculares em plantas cítricas. I. Método empregado. Revista Brasileira de Ciência do Solo, v.23, p.53-58, 1999a.

MELLONI, R.; CARDOSO, E.J.B.N. Quantificação de micélio extrarradicular de fungos micorrízicos arbusculares em plantas cítricas. II. Comparação entre diferentes espécies cítricas e endófitos. Revista Brasileira de Ciência do Solo, v.23, p.5967, 1999b.

MILLER, R.M.; REINHARDT, D.R.; JASTROW, J.D. External hyphal production of vesicular-arbuscular mycorrhizal fungi in pasture and tallgrass prairie communities. Oecologia, v.103, p.17-23, 1995.

NEUMANN, K.; GEORGE, E. Extraction of extraradical arbuscular mycorrhizal mycelium from compartments filled with soil and glass beads. Mycorrhiza, v.15, p.533-537, 2005.

NEWMAN, E.I. A method of estimating the total length of root in a sample. Journal of Applied Ecology, v.3, p.139-145, 1966.

NOGUEIRA, M.A.; CARDOSO, E.J.B.N. Colonização radicular e produção de micélio externo por duas espécies de fungos micorrízicos arbusculares em soja. Revista Brasileira de Ciência do Solo, v.24, p.329-338, 2000.

NOGUEIRA, M.A.; CARDOSO, E.J.B.N. Plant growth and phosphorus uptake in mycorrhizal rangpur lime seedlings under different levels of phosphorus. Pesquisa Agropecuária Brasileira, v.41, p.93-99, 2006.

PHILLIPS, J.M.; HAYMAN, A.S. Improved procedures for clearing roots and staining parasitic and vesicular-arbuscular fungi for assessment of infection. Transactions of the British Mycological Society, v.55, p.158-161, 1970.

SARRUGE, J.R.; HAAG, H.P. Análises químicas em plantas. Piracicaba: ESALQ, Departamento de Química, 1974. 56p.

SAS INSTITUTE. Procedure guide for personal computers. Release 6.11. 5.ed. Cary: Statistical Analysis System Institute, 1991.

SYLVIA, D.M. Activity of external hyphae of vesicular-arbuscular mycorrhizal fungi. Soil Biology and Biochemistry, v.20, p.39-43, 1988.

SYLVIA, D.M. Quantification of external hyphae of vesiculararbuscular mycorrhizal fungi. Methods in Microbiology, v.24, p.54-65, 1992.

Received January 18, 2006

Accepted April 10, 2007 